\title{
Addressing the Needs of Doctoral Students as Academic Practitioners: A Collaborative Inquiry on Teaching in Higher Education
}

\author{
Lisa J. Starr and Ashley DeMartini \\ McGill University
}

\begin{abstract}
This paper presents preliminary findings from a pilot study whose purpose was to explore how we, a tenure-track faculty member and a doctoral student, understood and developed our teaching practice when engaged in a formal faculty-student relationship. Using a hybrid of collaborative inquiry and collaborative self-study-which included verbal and written dialogue, interrogation, as well as observation-we sought to understand how that formal faculty-student relationship promoted the development of strong teaching pedagogy. The motivation for this study was a commitment to fostering highquality teaching in undergraduate courses in our faculty of education. Driving this study was the research question: How are we investigating and improving upon our practices as teachers in post-secondary education?
\end{abstract}

\section{Résumé}

Cet article présente les résultats préliminaires d'une étude pilote dont le but était d'explorer la façon dont nous, une professeure et une doctorante, avons compris et élaboré notre pratique d'enseignement lorsqu'engagées dans une relation formelle professeur-étudiant. En combinant recherche et autoétude collaborative, comprenant dialogue verbal et écrit, interrogation et observation, nous avons cherchéà comprendre comment cetterelation formelle professeur-étudiant favorisait l'évolution d'une pédagogie d'enseignement efficace. Le but de cette étude était d'assurer la qualité élevée des cours de premier cycle au sein de notre faculté d'éducation. La question de recherche à l'origine de cette étude était la suivante : Comment étudier et améliorer nos pratiques pédagogiques en matière d'enseignement postsecondaire? 
Unprecedented changes have occurred within universities. Neoliberalization of the academy has decreased public funds and increased the need to compete globally (Archer, 2008; Lorenz, 2014; Ramsden, 2003). Competing in a global knowledge-economy has required investments in a competitive research output model while simultaneously reducing expenditures, seeking non-public funding sources, and implementing structures to demonstrate transparency and accountability across university faculties (Henkel, 1997; Light \& Cox, 2001; Strathern, 2000). Class sizes have increased from the 1980s, and lecturers have been faced with a diverse student body who possess varying skills and learning needs (Cooper \& Robinson, 2000; Kokkelenberg, Dillon, \& Christy, 2008). The relationship between teaching and research within the university has been fraught with tension; to what extent teaching and research can be considered distinct or symbiotic activities remains to be seen (Barnett, 2005; Jenkins, 2003). Yet, teaching responsibilities have persisted in Canadian academia, particularly in faculties of education, where few positions have been research only. Given this reality, Ramsden (2003) has argued that investing in the quality of teaching has been one way for a university to distinguish itself competitively.

In the midst of universities' structural and financial overhaul, questions about teaching and its future role in academic institutions in coming decades have emerged. In some institutions, tenure-track positions have been disappearing in favour of contract lecture positions. On the one hand, job security has been eroding within the academy. On the other hand, these short-term contracts have created an opportunity for some doctoral students to gain valuable teaching experience (Cross \& Goldenberg, 2011; Thompson, 2003). In these uncertain times, how have doctoral students been learning to teach at undergraduate levels? This question is more than timely-it is imperative. Given the strong emphasis upon research as the requirement for doctoral degree fulfillment, what kinds of initiatives have addressed concerns around the quality of undergraduate teaching? Moreover, what measures have faculties of education taken to ensure that doctoral students succeed as contract lecturers?

This paper presents preliminary findings from a pilot study that took place in one faculty of education in central Canada. The purpose of the study was to explore an initiative that intended to address the growing need for doctoral students to succeed in teaching assignments. Specifically, this initiative included a tenure-track faculty member and a doctoral student's collaborative inquiry into their understanding of their teaching practice through engagement in a formal faculty-student relationship. This relationship was informed in part by literature on mentorship. Mentorship has been a common descriptor for relationships between doctoral students and tenure-track faculty members. Galbraith (2003) described mentoring as about "dialogue, caring, authenticity, emotion, passion and identity" (p. 2). When applied to the formal faculty-student relationship we formed, each of Galbraith's descriptors was accurate and applicable; yet, during the study, we avoided labelling our relationship as mentorship for two important reasons. First, in our experience, mentorship relationships have been ones wherein the more knowledgeable mentor imparted wisdom or knowledge to the less experienced mentee. This interaction has been premised on the intentional linear delivery of information from expert to novice. That expert-novice power dynamic has detrimentally permeated education. We intentionally chose to label our interactions and connections more generically as relationships. By doing so, we have communicated that our collaborations were more than 
power-imbalanced mentorships or political partnerships. Furthering the importance of collaboration, we emphasized that the benefits for the doctoral student and the tenuretrack faculty member, while different, were not of disproportionate importance. Instead, the benefits were individualized based on the distinct needs of the doctoral student and of the tenure-track faculty member. For example, the latter had taught at the high school and university levels for over 20 years, so her desire to understand assessment practices was informed by that practice, whereas the doctoral student, who had substantially less teaching experience, was motivated by different knowledge. Although some may consider the term relationships too broad, we addressed this by including the adjective formal to the faculty-student relationship to communicate its professional academic structure.

We used a hybrid of collaborative inquiry and collaborative self-study to understand how this formal faculty-student relationship promoted the development of a strong teaching pedagogy. Within that methodological hybrid, we engaged in verbal and written dialogue as well as observation. To embody reflexive practice, we interrogated the various dialogues and observation notes to seek out recurring themes. Embedded in the motivation for this exploratory study was our commitment to fostering high-quality teaching and assuring quality in undergraduate courses that take place within our faculty of education. The research question that drove this study was: How are we investigating and improving upon our practices as teachers in post-secondary education? Conceptually, two key ideas formed the backbone of our understanding and procedure: (1) critical reflexivity and (2) relational, dialogic pedagogy.

\section{Existing Scholarship on Learning to Teach in Higher Education}

We explored a broad and rich swathe of literature on the scholarship of teaching, from a variety of academic perspectives. Saroyan and Frenay's (2010) investigation provided insight into university-level pedagogy in North America and Europe. While some research tended towards the instructional "how-to" manual for new course lecturers (Dominowski, 2014; Duch, Groh, \& Allen, 2001; Martinez-Pons, 2003), other research focused on the intersection of theory and practice (Kegan, 2000; Kyle, 2011; Sanford, Starr, \& Mimick, 2015). The research we present in this paper is situated in that intersectional space. Further, our research responded to Fry, Ketteridge, and Marshall's (2008) call for post-secondary educators to examine individual perceptions and understandings of the teaching world. Of significance to our pilot project was Frye et al.'s (2008) experiential framework, wherein understanding was represented as a dynamic and fluid process shaped and reshaped by experience itself. Researchers have stressed the importance of examining postsecondary teaching practices in the classroom spaces where those practices occur (Cerbin \& National Teaching and Learning Forum, 2011). In our formal faculty-student relationship, the tenure-track faculty member observed the doctoral student teaching a media literacy class. Conversely, the doctoral student also observed the tenure-track faculty member teaching an undergraduate seminar. We followed Cerbin et al.'s (2011) example by jointly designing, teaching, studying, and refining teaching experiences, including the learning problems that arose. The resulting analysis highlighted a key theme that focused our attention on how our instructional choices impacted student learning. The impact of instructional choices on our confidence as teachers was another key theme that emerged. As we will discuss in later sections of this paper, dialogue, collaboration, and reflexivity were crucial components of our inquiry into what it meant to teach. 
Postareff, Lindblom-Ylänne, and Nevgi (2008) looked at a variety of instructional approaches modelled by university instructors, based on the latter's pedagogical training. They argued that professionally trained undergraduate teachers, like those who have a degree in education, were more likely to engage students in deep learning. The authors pointed to Gibbs and Coffey (2004), who examined how university teachers' conceptions of instruction informed their approach to teaching. A key finding between their two control groups of undergraduate teachers revealed that the control group without any training became increasingly teacher-centered over the duration of a year, whereas teachers in the control group receiving training became more attuned to a student-centered practice. The importance of creating a student-centred classroom cannot be understated. In years past, the bulk of teaching and learning modelled a stand and deliver style. The underlying assumption of such a model was that the teacher possessed the required knowledge otherwise inaccessible to students. The proliferation of the Internet has dramatically increased one's access to information. For the preparation of undergraduate teacher candidates, the similar sage on the stage model has lost its status as a viable or effective teaching practice. Specifically in faculties of education, undergraduate students as prospective teachers have expected not only to learn about good pedagogy, but also to see this same pedagogy modelled by course instructors. These expectations have caused dissonance when doctoral students hired as course lecturers have not had prior training as K-12 teachers. In many cases, the majority of doctoral students' experiences around teaching and learning have come from a disengaging and ineffective lecture style modelled upon their previous post-secondary undergraduate classes. Knowing this, we built our research upon the desire to understand how doctoral students have developed good pedagogical practices. In light of how universities have restructured teaching positions, the quality of teaching that doctoral students must bring to their undergraduate teaching is crucial to universities maintaining quality undergraduate education.

\section{Doctoral Students: Teaching Undergraduate Education}

With universities undergoing neoliberal restructuring, academic departments have been forced to deal with eroding budgets and the disappearance of tenure-track positions. In some cases, budget shortfalls have resulted in less financial support for doctoral students. Contract instructor positions or single-course teaching opportunities have meant semi-consistent incomes and opportunities for graduate students as academic practitioners within their faculties. Many doctoral students, while knowledgeable about course content, have had little experience teaching at an undergraduate level. Of particular concern has been how faculties have facilitated quality teaching for their undergraduate students if the doctoral students hired have had little to no experience. With this in mind, Ramsden (2003) argued that learning has been at the "heart of the higher education enterprise even at the most ambitious 'research-led' institutions" (p. xii). In this paper, we extend Ramsden's observation, suggesting that learning how to teach in post-secondary settings should also be at the heart of any higher education institution. In the following sections, we inquire into the art of teaching through a conceptual framework of critical reflexivity as well as a dialogic, relational pedagogy.

The McGill context-how this project came to fruition. The impetus for this research began humbly via informal conversations and personal concerns raised by the 
authors. Through these conversations, we became aware of doctoral students' anxiety and concern about teaching undergraduate classes. Although we work in a faculty of education, understanding the pedagogy of teaching has been neither second nature nor a requirement for instructors in our institution. As doctoral students sought to develop their portfolios in preparation for work in academia, our initial anecdotal findings revealed gaps in the teaching aspect of doctoral students' dossiers. In some cases, doctoral students had no teaching experience, while others had taught single classes with marginal success. In raising the question of how graduate students have learned to teach, several suggestions for addressing the issue were identified, including the possibility of formal faculty-student relationships. As a result, two formal faculty-student relationships were voluntarily formed to explore how doctoral students learned to teach. Each of the formal faculty-student relationships provided the doctoral students involved with opportunities to interrogate their pedagogical and experiential understanding of how to teach in undergraduate education. One student, the second author of this article, took up this opportunity while teaching an undergraduate class on educational technology. Another student collaborated with a faculty member in a science education class, where they planned, designed, and taught classes together. In addition, both of these doctoral students were able to demonstrate on their professional dossiers how they had participated in professional development as academic practitioners. This paper focuses on the formal faculty-student relationship between the first author (tenure-track faculty member) and the second author (doctoral student, teaching educational technology).

\section{Conceptual Framework}

The formal faculty-student relationship included dialogue and observation that led to an ongoing collaborative analysis of our individual teaching practices and collective understanding of teaching. Critical reflexivity and relational, dialogic pedagogy have informed our evolving understanding of teaching.

\section{Critical Reflexivity}

Teacher educators have frequently asked pre-service teachers to demonstrate learning through reflection. Reflective practice has been a commonly held exercise in teacher education because it has provided a "critical underpinning of growth and learning" (Ryan, 2005, p. 1). Yet, teacher educators have often forgotten that being reflective has also been critical to their own growth and development. We have extended the notion of reflection to a broader interpretation of being reflexive. Practically, being reflexive warrants more than looking back to contemplate events. Instead, reflexivity requires consideration of how the actions and ideas associated with events have contributed to the construction of meaning. From these new meanings, reinterpretations of actions emerge to inform choices (Willig, 2001). Danielewicz (2001) summarized the importance of a reflexive stance:

Reflexivity is an act of self-conscious consideration that can lead people to a deepened understanding of themselves and others, not in the abstract, but in relation to specific social environments ... [and] foster a more profound awareness ... of how social contexts influence who people are and how they behave. ... It involves a

person's active analysis of past situations, events, and products, with the inherent 
goals of critique and revision for the explicit purpose of achieving an understanding that can lead to change in thought or behaviour. (pp. 155-156)

In the case of doctoral students who have been teaching, the presence of reflexive practice has been uncommon, in part because such practice has not been not modeled or discussed in ways that would have led doctoral students to embed reflexivity within their teaching practice. While doctoral students may have examined and revised the learning opportunities they constructed for students, in our experience, doctoral students have rarely engaged in the active analysis advocated by Danielewicz (2001) because they have not realized it could and should have been part of their pedagogical repertoire. During our research, we intentionally engaged in dialogic forms of reflexion that led to deeper, more critical thinking of what it meant to teach undergraduate education.

We also considered a critical attitude to be necessary in adopting a reflexive stance. To engage in critical reflexivity, teachers must analyze the foundations of their beliefs (Bray, Lee, Smith, \& Yorks, 2000). The subsequent analysis then informs a degree of action based on those findings. Ryan (2006) believed that "critical skills allow people to recognize unstated, implicit and subtle points of view and the often invisible or taken-forgranted conditions that provide the basis for these stances" (p. 114). By adopting a critical stance, we were able to interrogate our own default position to the lecture style that is so common to higher education. We were also able to look deeper towards the triggers that caused us to revert to a lecture style.

Throughout undergraduate and graduate education, doctoral students have experienced lectures as an ineffective teaching approach.

More than 700 studies have confirmed that lectures are less effective than a wide range of methods for achieving almost every educational goal you can think of. Even for the straightforward objective of transmitting factual information, they are no better than a host of alternatives, including private reading. Moreover, lectures inspire students less than other methods, and lead to less study afterwards. (Gibbs, 2013, para. 6)

That the lecture style has been unsuccessful is only part of the problem of ineffective undergraduate teaching. The more significant issue has become a concern over identifying and implementing alternatives. Without understanding and successfully experiencing other styles of teaching, doctoral students have inevitably replicated what they knew about teaching, thus perpetuating a cycle of ineffective instruction.

\section{Relational, Dialogic Pedagogy}

Given that relationships have been central to our understanding of education, we have asserted that teaching practice must be viewed relationally. Conceptually, relationality has required individuals to become weavers of a fabric "fashioned by transforming divisive incompatibilities into creative tensions" (Allan \& Evans, 2006, p. 9). ThayerBacon (2003) suggested that relationality was about a "humble approach to knowing" (p. 255), wherein the intention of interactions should be to understand the other person as much as what that person has said. To be humble in knowing is to listen without critique, not just to the words but to what comes with those words: the perspectives, 
emotions, and experiences that the individuals have shared. While teaching and learning have been inherently relational, the actions of teachers and learners have not always reflected a relational stance. It has been difficult to diverge from the long history of traditionalist structures in education. If doctoral students have experienced teaching as a transmissive act of information delivery, they have likely replicated the same model in the absence of other possible models. Further, the experience of teaching may have been isolating, particularly for doctoral students who are content experts but still developing their skills as pedagogues.

We intentionally chose a relational, dialogic approach as an alternative to a lecture style of teaching. A relational, dialogic approach brought to the forefront our knowledge and experience (Lysaker \& Furuness, 2011). We considered our knowledge through the sharing of reflexive writing, blog responses, and social dialogue. Through these forms of personal and social dialogue, we interrogated our beliefs about the nature of teaching while having considered ourselves as active agents in the generation of meaning and understanding. The belief in knowledge as experiential, practical, propositional, and presentational was embedded in our research process (Byrne-Jiménez \& Orr, 2007). Experiential knowledge was derived from interactions with the people, places, and things associated with our teaching, whereas our practical knowledge was developed through our actual practice of teaching. Our propositional knowledge was created through our understanding of the accepted knowledge of teaching as well as theories associated with teaching. Our presentational knowledge was expressed in the act of teaching as we observed each other. The initial interactions between the tenure-track faculty member and doctoral student were dialogue as conversation (Renshaw, 2004). Such dialogue established mutual understanding through the promotion of sharing information and experiences, which at the same time revealed different attitudes and opinions (Renshaw, 2004). One example was Lisa's attitude towards assessment versus Ashley's attitude. While we both agreed that formative assessment was important, how we engaged in that formative assessment reflected the degree of comfort each of us had with feedback and grading.

The ideas that we shared were in turn prompted by what each other said and shared. As we continued to meet and contextualize our conversations in light of our experiences in the classes we taught and observed, our conversations shifted to dialogue as inquiry (Renshaw, 2004). Dialogue as inquiry is different than dialogue as conversation, in that each inquirer continues to contribute their views but those views are actively interrogated and questioned by other inquirers, with the intention of clarification as well as the achievement of a "working consensus or tentative agreement" (Renshaw, 2004, p. 9). Referring back to the assessment example, we continued to examine samples of assessments, such as rubrics, for commonalities, but more importantly for problems that may have been interfering with student success.

\section{Research Methodology}

The tenure-track faculty member and the doctoral student met frequently throughout the course of one teaching term. These meetings were sometimes scheduled and other times spontaneous. During these meetings, we focused on what had happened in our classrooms and in the conversations we had had with students that raised questions or concerns for us. We also addressed personal challenges and issues that we had faced in 
our goals and ideas about teaching. Qualitative data collection provided three sources of data: recorded dialogue (audio recorded meetings), written dialogue (blog posts), and self-reflection. In addition, each author observed the other teach, making time following the teaching episodes for informal discussion. Observations were shared verbally and reflected upon in the blog posts.

\section{Collaborative Inquiry}

Our research methodology for this pilot study was a hybrid of collaborative inquiry and collaborative self-study. Featured in collaborative inquiry has been the purposeful need to maintain flexibility in developing the inquiry so as to allow for co-inquirers to have maximum potential, not just for participation but also for ownership of the process and results. Bray et al. (2000) defined collaborative inquiry as "a process consisting of repeated episodes of reflection and action through which a group of peers strives to answer a question of importance to them" (p. 6). Byrne-Jiménez and Orr (2007) further characterized collaborative inquiry as being informed in large part by lived experience as a "way of studying a problem (that) leads to the creation of new knowledge, new courses of action, and the empowerment of participants" (p. 43).

Engaging in collaborative inquiry required us to have maintained an intentional interplay between reflection and making sense, often through personal reflexive writing and the interrogation of our experiences and actions in the classroom (Heron, 1996). Throughout the winter semester, we expressed our ideas of teaching and learning by reflecting on our past and present experiences. Explanations and discussions of how our understandings shaped our beliefs and actions about teaching were included in our reflections. We examined how our ongoing dialogue was informing our teaching.

Collaborative inquiry also required explicit attention, through agreed upon procedures to validate the inquiry and its findings (Heron, 1996). Our conception of validity was less quantitatively traditionalist and more rhizomatic. LeGrange and Beets (2005) built on the work of Lather (1993) to challenge conventional notions of validity through metaphor, wherein the tree represented the modernist model of knowledge and the rhizome was a model of postmodern knowledge. To have behaved rhizomatically is to have acknowledged a "move from hierarchies to networks and the complexity of problematics where any concept, when pulled, is recognized as connected to a mass of tangled ideas, uprooted, as it were, from the epistemological field" (p. 117). Our understandings of teaching were more akin to a mass of complex tangles-a weedy and unpredictable, interconnected garden. As we each revealed some of our fears, uncertainties, and beliefs, further questions emerged, taking us down a rhizomatic, non-linear path that criss-crossed itself numerous times. Each time the figurative path crossed over itself, our previous understandings were subject to the reinterpretation demanded of reflexive practice.

Collaborative inquiry also required us to integrate presentational knowledge through the use of aesthetic, expressive forms, propositional knowing through words and concepts, and practical knowing through experiences. In addition to being informative about the topic of the research, our experience was transformative, in that many aspects of the inquiry brought about an awakening or awareness (Heron, 1996). Our transformed awareness led to action, which in turn led to a changed way of being teachers. This transformed sense was focused less on doubt and uncertainty and more on confidence formed through 
our relational study of what it meant to teach (Heron \& Reason, 1997). As a result of our continued dialogue, each week we entered into our classrooms with new understandings to inform our actions as teachers.

\section{Collaborative Self-Study}

For this pilot study, notions of collaborative inquiry and collaborative self-study overlapped. Given that the two authors were also the participants, our approach to the research included elements of self-study. Drawing on LaBoskey (2009), the self-study aspect of our research adhered to five characteristics. First, the study of our practice as teachers was self-initiated and focused on understanding our teaching practices. Second, we were motivated to enhance the overall quality of teaching practice so as to improve the undergraduate programme. Third, our approach was interactive in that we encouraged (i) each other to interrogate our teaching choices, (ii) students to question teaching practices that we demonstrated and modelled, and (iii) colleagues to discuss our research. Fourth, the study was qualitative in that we collected and analyzed our written and verbal dialogue, then we followed this with verbal reflective dialogue about the analysis. Finally, we addressed validity as a rhizomatic construct in line with a postmodern view of knowledge (Lather, 1993).

Rather than a linear progress, rhizomatics is a journey among intersections, nodes, and regionalizations through a multi-centered complexity. As a metaphor, rhizomes work against the constraints of authority, regularity, and commonsense, and open thought up to creative constructions. They are "on the ground," immanent, with appeal not to transcendental values but to "their content of "possibilities', liberty or creativity." (Lather, 1993, p. 680)

Our understanding of teaching in general and ourselves as teachers developed through the interplay between each other, between us and students, and between us and our reflection on the actions taken and words spoken. Evidence of each of the features discussed here can be seen in conceptual threads that follow. In the next section, we share excerpts of Ashley's reflections and her subsequent sense-making as she considered the skills and dispositions required of teaching. We decided to highlight Ashley's learning because of this paper's focus on doctoral student learning. Our intention in sharing these excerpts is to provide a first-person, intimate account of Ashley's meaning-making process of her teaching, as prompted by the questions, dialogues, and observations that took place during the research.

\section{Conceptual Threads: Ashley's Story}

Walking up the stairs to my sixth-floor classroom, my stomach flutters with anticipation, excitement, and nerves. I try to quiet the various narratives that race through my head with a couple of deep breaths, and it's enough to get me to the door... I pause, and suddenly think, how am I expected to know how to teach if this entire experience is new to me? Seventy-two is the number of faces that look back at me when I teach. It is also the number of people I hope to inspire to think pro- 
actively about integrating technology into their emerging teaching practice. And somewhere amidst those faces and my lofty aspirations lurks the dogged question, "What the f@\#\$ am I doing?" Teaching is terrifying, and learning to teach undergraduate education has been one of the most terrifying professional endeavours yet. (January, 2015)

\section{Reflexion 1: Seventy-Two Faces}

Over a semester's duration, students looked to me as a leader of the course, a facilitator of their own professional growth as pre-service teachers, and a resource for their learning. My words, ideas, and actions have been interpreted 72 times over the course of 14 weeks. Learning to teach has been a transformative ordeal-one that has demanded that I become comfortable with: setting and maintaining class boundaries; playing the authoritative role responsibly; pushing students to venture beyond their comfort zones even if I am afraid; knowing when to let go and let the class determine our direction; being okay with not knowing, and calling on the class as a resource to address certain questions; assessing students' work; and finally, making mistakes and having the courage to own up to them in front of all 72 students.

Throughout the pilot project, Lisa and I kept a private blog where we had many discussions about teaching. We used this digital space to air troubling thoughts and consternating feelings about our profession. Mostly, this became a lucid space-through my text-based exchanges with Lisa, I could work through some of the challenging issues that arose while I taught my course. The way I discussed my concerns in my blog entries as an emerging post-secondary educator interacted with, and developed through, our dialogic encounters. This space was different from our face-to-face conversations because it provided me time/space to absorb the meaning emerging from the dialogue itself, and not simply as the separate entities of what I said or Lisa said. The following are a series of additional excerpts from my blog entries that capture this process above, as well as demonstrate how I applied the insights gained from our exchanges in my practice. They touch upon themes of pedagogical failure and difficult content. They reflect the method of dialogue as a source for transforming my teaching practice.

I was fixated on covering it all. I think this also stems from the way syllabi are often thematically structured, creating a sense of urgency for me - a sort of, "if I don't get to this, I never will" feeling. (March, 2015)

\section{Reflexion 2: On Pedagogical Failure}

For me, learning to teach has involved learning how to move beyond moments of failure so as to improve upon and strengthen my pedagogical approach for the next time. There is substantial literature on the experience of failure, but for the purposes of this reflection, I remain with my experience because no matter how well-read I could have been, no theory or idea could have mitigated the initial sting of failing, especially as a teacher. However, I could move away from this debilitating feeling precisely because I had the dialogic space of the blog to explore honestly with Lisa the events that had transpired.

From failure I learned how important it is to not overload students with content, especially when it may be about conceptually complex topics. In this particular instance, the 
class focused on race and racialization in the media. I realized that I had tried to pack too much content into this class because I was afraid-afraid, perhaps, that I would not be able to meaningfully lead a conversation about race and racialization, afraid that maybe a student may challenge me in front of the entire class and I would not know what to say or do and/or would lose any or all credibility as their leader. Bolgatz (2005) pointed out that teachers can rush through content that makes them uncomfortable, missing opportunities to delve into a rich discussion with students about, for example, the issues of race and racism. Regardless of what I did or did not do, this kind of thinking (detailed above) set me up for failure, since the content dominated our class time, and I did not allow enough time for the students to process the material I covered-or perhaps I expected too much from one class. Save for a few students' responses, most of my questions were met by silence. Nobody felt comfortable speaking, and I did not know how to get them to speak. The excerpts included at the beginning of this section really represent my struggle as an emerging academic practitioner to come to terms with the challenge of teaching and the inevitable failure I will face at times.

"He didn't like being lumped in with the label of 'white people' because he felt betrayed by group representation.” (March, 2015)

\section{Reflexion 3: On Difficult Content}

Teaching about race and racialization in the media is worthy of its own course, so perhaps trying to address it in the span of one class is an indication of a design flaw of the course I inherited as a course lecturer. I revisit the same class discussed above due to the impact it has had on my own teaching practice. About a year ago, I came across Ullucci's (2012) Knowing We Are White: Narrative as Critical Praxis, wherein the author discussed her experiences of working with white pre-service teachers in order to develop an understanding about their whiteness and how it shaped their own emerging practice. Inspired by Ullucci, and being white myself, I wanted to introduce my class to this notion so they could problematize and engage with it in their own discussions on teaching. At the same time, I was aware that these kinds of conversations can eclipse the actual issues related to racial injustices. Thus, the challenge as the teacher was to bring this consideration into the class conversation as a subtext to the larger discussion on racism in a manner that did not dominate but, rather, deepened students' understanding of the topic. I showed the students an interview with the director of a documentary entitled, The Whiteness Project (Dow, 2014), wherein 27 participants from one city were interviewed to discuss how they understood their experiences as a white person. One of the students, a white male, who is particularly thoughtful, came to me during break to express his concern. He was very troubled that (i) I had shown a clip from PBS (he questioned the validity of my source) and (ii) the project took a sample of 27 individuals as being representative of white people in general. His concerns reflected his reaction to the idea of "white" becoming a racial construct with social attributes (attitudes, styles, and perspectives).

But this is exactly the point I wanted to demonstrate to my students: discussions on deconstructing the processes of race should consider the function and privilege of whiteness, especially its attribute of invisibility. When being "white" is suddenly made visible as a socially constructed category of race, many white students are left confused, frustrated, 
and angered. The point I am trying make is that often, non-white students are judged, categorized, and seen by their group identity, while many white students are primarily seen as individuals first. However, when the idea and racial construct of "white" is made visible as a group identity, the privilege of invisibility disappears, and many white students must also challenge and examine generalizations about whiteness and white-skin privilege. Ullucci (2012) stated, "The challenge arises in helping teachers come to terms with the ways Whiteness and privilege function ... and how they can either be complicit with or rupture these mechanisms" (p. 90). Although I did mention this to the student when he came up to speak with me, I was in such a rush when presenting this to the entire class that I left some of it unsaid. However, in the following class, I returned to this point as part of my debrief. Students had had some time to digest the content from the last class, perhaps making the point all the more powerful. I chose the above excerpt to convey the complexity of discussing race in the classroom but also to demonstrate how students can gain profound insights when the instructor is willing to work with them through their thinking. Moreover, this discussion's significance with regards to faculty-student relationships lies within the way our blog exchanges supported me in thinking through how failure, and my reaction to the students' silence, became a critically reflexive space in which to consider my unexamined ideas about teaching. As well, my online exchanges with Lisa supported my reflections about the necessary balance between content and the time for dialogue in my own class.

\section{Implications for Further Faculty-Student Learning}

The value of creating a formal faculty-student relationship that afforded opportunities for deep reflexion and collaborative learning has been profound. Although we have focused here on Ashley's learning as a doctoral student, the learning experience was equally profound for Lisa. As an advocate for reflexive practice with her students, Lisa frequently espoused the merits of such practice but did not always maintain a focus on her own reflexive practice. By participating in the ongoing dialogue, Lisa was able to re-interrogate her beliefs, specifically about effective assessment and teaching identity. Included in that interrogation was a more nuanced understanding of the emergence of power dynamics in the relationships between teacher and student and how those power dynamics at times negatively influence learning. Lisa also reconnected with the importance of formative assessment in higher education yet identified the challenges in modeling such assessment. As a result, she looked to her own course for ways to improve formative assessment practices.

One outcome of this pilot study has been the formation of a collaborative inquiry group of seven doctoral students teaching undergraduate courses, plus several faculty members. The group's shared purpose has been to discuss, compare, and reflect upon individual and collective teaching practices; at the time of writing this article, the collaborative inquiry initiative had just begun, so we are yet to reflect on the impact of this group. Another outcome of this pilot study was a framework for a graduate-level course that will promote a reflexive, dialogical, and relational interrogation of beliefs about teaching while simultaneously applying emerging understandings to a teaching context. We spend the rest of this section discussing the potential implications of this course.

Through course assignments, particularly reflexive writing/recording, doctoral students will be asked to think about themselves as knowers and thinkers, to examine their beliefs about teaching, research, and leadership, and to consider themselves as active 
agents in educational contexts. During this critical self-examination, the potential for transformation will emerge, as doctoral students collaboratively and dialogically explore alternative understandings of how they see the world and their roles within it (Cranton, 2006; Lysaker \& Furuness, 2011). Based on a collaborative inquiry process, doctoral students will use their emerging knowledge of themselves as educators and their theoretical understanding of constructing rich learning experiences for undergraduate students to construct a series of learning opportunities at the undergraduate level. As doctoral students interrogate their knowledge and understanding, they will gain valuable insight into a variety of teaching methodologies and into the scholarship surrounding what it means to be an educator in higher education.

Doctoral students will use critical reflexive journals to record entries of self-inquiry to understand personal and professional perspectives that influence their study and interpretations of best practices. Journal entries will serve as catalysts for conversations about teaching, wherein the students can reassess their presuppositions, challenge the validity of their interpretations, and subsequently correct any distortions in action resulting from such reassessments (Mezirow, 1994). Engagement in the critical reflexive journal will advance the practice of reflexivity by requiring doctoral students to direct their thoughts back onto themselves in order to examine their theories, beliefs, knowledge, and actions in relation to the practice of teaching. These interpretations of experiences, and insights into how people's interpretations came into existence, will emerge as reflexive knowledge (Barry \& O’Callaghan, 2008).

The development of this course, with its emphasis on reflexive, dialogic, relational practice, has been a direct extension of our pilot research. Our hope is that this research will become a valuable contribution to the scholarship of teaching in faculties of education. More importantly, not only have we responded to the criticisms of teaching styles in faculties of education, but also we have taken action to provide doctoral students with the means to build and improve their practice. Finally, we hope that through this work, our actions will contribute to strengthening the standard of teaching in undergraduate teacher education.

\section{References}

Allan, G., \& Evans, M. D. (2006). Introduction: A different three Rs for education in context. In G. Allan \& M. D. Evans (Eds.), A different three Rs for education: Reason, relationality, rhythm (pp. 1-16). New York, NY: Rodopi.

Archer, L. (2008). Younger academics' constructions of "authenticity", "success" and professional identity. Studies in Higher Education, 33(4), 385-403.

Barnett, R. (2005). Reshaping the university: New relationships between research, scholarship and teaching. Columbus, $\mathrm{OH}$ : McGraw-Hill International.

Barry, P., \& O'Callaghan, C. (2008). Reflexive journal writing: A tool for music therapy student clinical practice development. Nordic Journal of Music Therapy, 17(1), 55-66. doi:10.1080/o8098130809478196

Bolgatz, J. (2005). Talking race in the classroom. New York, NY: Teachers College Press.

Bray, J. N., Lee, J., Smith, L. L., \& Yorks, L. (2000). Collaborative inquiry in practice: Action, reflection, and meaning making. Thousand Oaks, CA: Sage. 
Byrne-Jiménez, M., \& Orr, M. T. (2007). Developing effective principals through collaborative inquiry. New York, NY: Teachers College Press.

Cerbin, B., \& National Teaching and Learning Forum. (2011). Lesson study: Using classroom inquiry to improve teaching and learning in higher education. Sterling, VA: Stylus.

Cooper, J. L., \& Robinson, P. (2000). The argument for making large classes seem small. New Directions for Teaching and Learning, 81, 5-16.

Cranton, P. (2006). Understanding and promoting transformative learning: A guide for educators of adults. San Francisco, CA: Jossey-Bass.

Cross, J. G., \& Goldenberg, E. N. (2011). Off-track profs: Non-tenured teachers in higher education. Cambridge, MA: MIT Press.

Danielewicz, J. (2001). Teaching selves: Identity, pedagogy, and teacher education. Albany, NY: SUNY Press.

Dominowski, R. L. (2014). Teaching undergraduates. New York, NY: Routledge.

Dow, W. (Producer \& Director). (2014). The whiteness project [Interactive investigation]. New York, NY: Studio Kudos.

Duch, B. J., Groh, S. E., \& Allen, D. E. (2001). The power of problem-based learning: A practical "how to" for teaching undergraduate courses in any discipline. Sterling, VA: Stylus.

Fry, H., Ketteridge, S., \& Marshall, S. (Eds.). (2008). A handbook for teaching and learning in higher education: Enhancing academic practice. New York, NY: Routledge.

Galbraith, M. W. (2003). Celebrating mentoring. Adult learning, 14(1), 2-3.

Gibbs, G. (2013, November 23). Lectures don't work, but we keep using them. Times Higher Education. Retrieved from https://www.timeshighereducation.co.uk/news/ lectures-dont-work-but-we-keep-using-them/2009141.article

Gibbs, G., \& Coffey, M. (2004). The impact of training of university teachers on their teaching skills, their approach to teaching and the approach to learning of their students. Active Learning in Higher Education, 5(1), 87-100.

Henkel, M. (1997). Academic values and the university as corporate enterprise. Higher Education Quarterly, 51(2), 134-143.

Heron, J. (1996). Cooperative inquiry: Research into the human condition. Thousand Oaks, CA: Sage.

Heron, J., \& Reason, P. (1997). A participatory inquiry paradigm. Qualitative Inquiry, 3(3), 274-294.

Jenkins, A. (2003). Reshaping teaching in higher education: Linking teaching with research. London, UK: Psychology Press.

Kegan, R. (2000). What "form" transforms?: A constructive-developmental perspective on transformational learning. In J. Mezirow (Ed.), Learning as transformation: Critical perspectives on a theory in progress (pp. 3-34). San Francisco, CA: Jossey-Bass. 
Kokkelenberg, E. C., Dillon, M., \& Christy, S. M. (2008). The effects of class size on student grades at a public university. Economics of Education Review, 27(2), 221-233.

Kyle, E. J. (2011). Discerning praxis: At the intersection of theory, practice and reflection in the field of spiritual formation. Retrieved from http://www.academia. edu/1433128/Discerning_Praxis_At_the_Intersection_of_Theory_Practice_and_ Reflection_in_the_Field_of_Spiritual_Formation

LaBoskey, V. K. (2009). "Name it and claim it": The methodology of self-study as social justice teacher education. In D. L. Tidwell (Ed.), Research methods for the self-study of practice (pp. 73-82). Dordrecht, Netherlands: Springer. doi:10.1007/978-1-4020-9514-6_5

Lather, P. (1993). Fertile obsession: Validity after poststructuralism. The Sociological Quarterly, 34(4), 673-693.

LeGrange, L., \& Beets, P. (2005). (Re)conceptualizing validity in (outcomes-based) assessment. South African Journal of Education, 25(2), 115-119.

Light, G., \& Cox, R. (2001). Learning and teaching in higher education: The reflective professional. London, UK: Paul Chapman.

Lorenz, C. (2014). Fixing the facts: The rise of new public management, the metrification of "quality" and the fall of the academic professions. Moving the Social, 52, 5-26.

Lysaker, J. T., \& Furuness, S. (2011). Space for transformation: Relational, dialogic pedagogy. Journal of Transformative Education, 9(3), 183-197. doi:10.1177/1541344612439939

Martinez-Pons, M. (2003). The continuum guide to successful teaching in higher education. New York, NY: Continuum.

Mezirow, J. (1994). Understanding transformation theory. Adult Education Quarterly, 44(4), 222-232.

Postareff, L., Lindblom-Ylänne, S., \& Nevgi, A. (2008). A follow-up study of the effect of pedagogical training on teaching in higher education. Higher Education, 56(1), 29-43.

Ramsden, P. (2003). Learning to teach in higher education. Oxford, UK: Routledge.

Renshaw, P. D. (2004). Dialogic learning, teaching and instruction. In J. van der Linden \& P. Renshaw (Eds.), Dialogic learning: Shifting perspectives to learning, instruction, and teaching (pp. 1-15). Norwell, MA: Kluwer Academic Publishers.

Ryan, J. (2006). Inclusive leadership. San Francisco, CA: Jossey-Bass.

Ryan, T. (2005). When you reflect are you also being reflexive? The Ontario Action Researcher, 8(1). Retrieved from http://oar.nipissingu.ca/PDFS/V812E.pdf

Sanford, K., Starr, L. J., \& Mimick, K. (2015). Asking, telling, challenging, and listening: Curriculum theorizing of teacher education programs. Manuscript submitted for publication.

Saroyan, A., \& Frenay, M. (2010). Building teaching capacities in higher education: A comprehensive international model. Sterling, VA: Stylus.

Strathern, M.(Ed.). (2000). Audit cultures: Anthropological studies in accountability, ethics, and the academy. New York, NY: Psychology Press. 
Thayer-Bacon, B. (2003). Relational “(e)pistemologies”. New York, NY: Peter Lang.

Thompson, K. (2003). Contingent faculty and student learning: Welcome to the strativersity. New Directions for Higher Education, 123, 41-47.

Ullucci, K. (2012). Knowing we are White: Narrative as critical praxis. Teaching Education, 23(1), 89-107.

Willig, C. (2001). Introducing qualitative research in psychology: Adventures in theory and method. Philadelphia, PA: Open University Press. Retrieved from http:// mcgraw-hill.co.uk/openup/chapters/o335205356.pdf

\section{Contact Information}

Lisa J. Starr

Department of Integrated Studies in Education

Faculty of Education

McGill University

lisa.starr2@mcgill.ca

Lisa J. Starr is an assistant professor at McGill University in the Department of Integrated Studies in Education. Her teaching career led her from Canada to Pakistan, Kuwait, Mongolia, and back to Canada and created a passion for the study of the relationships between identity and culture, school leadership, and the preparation of teachers. Lisa strives to facilitate experiences beyond simple show-and-tell, to create transformative learning environments. Her current research focus is the use of autoethnography and self-study as means to investigate, understand, and make meaning of $21^{\text {st }}$-century leading and learning.

Ashley DeMartini is a doctoral student at McGill University in the Department of Integrated Studies in Education. For the past two years, she has taught an introductory course to educational technology and media within the McGill Faculty of Education. She is committed to developing her practice as a post-secondary educator. Her research interests include digital media production, visual methodologies, and teacher education. 